\title{
Hubungan antara Partisipasi Pendidikan dan Pertumbuhan Ekonomi: Studi Kasus di Indonesia
}

\section{Relation between Education Participation and Economic Growth: The Case of Indonesia}

\author{
Wahyudayanto Utama ${ }^{1}$, Nina Soesanti ${ }^{2}$ \\ ${ }^{1}$ Universitas Pendidikan Indonesia, Bandung, Jawa Barat, Indonesia \\ ${ }^{2}$ PPPPTK IPA, Bandung, Jawa Barat, Indonesia \\ wahyudayanto@gmail.com,ninasoesanti@gmail.com
}

Naskah diterima tanggal 20/03/2019, direvisi akhir tanggal 22/04/2019, disetujui tanggal 30/04/2019

\begin{abstract}
Abstrak
Pendidikan dipercaya sebagai salah satu unsur yang dapat menumbuhkan perekonomian negara. Di Indonesia terjadi peningkatan partisipasi siswa untuk tingkat menengah dan tinggi dari tahun 1994 - 2017 dan diwaktu yang bersamaan terjadi juga pertumbuhan ekonomi yang tinggi. Penelitian ini akan mencari hubungan antara partisipasi Pendidikan tingkat dasar, menengah, tinggi dan Produk Domestik Bruto (PDB). Data yang digunakan pada penelitian ini adalah data sekunder tentang partisipasi siswa dan PDB di Indonesia yang diambil dari Biro Pusat Statistik (BPS). Metode yang digunakan dalam mencari hubungan jangka pendek adalah uji Granger Causality, sedang untuk hubungan jangka panjang digunakan metode Vector Error Correction Model (VECM). Variabel yang digunakan pada penelitian ini adalah Angka Partisipasi Kasar (APK) Sekolah Dasar (SD), Sekolah Menengah Pertama (SMP), Sekolah Menengah Atas (SMA), Perguruan Tinggi (PT) dan PDB. Untuk uji stasioner variabel dan redisual digunakan uji Augment Dickey Fuller (ADF). Pada uji ADF diperoleh hasil bahwa variabel APK SD dan APK SMP stasioner pada tingkat Level, sehingga kedua variabel tersebut dihilangkan dari model awal. Hasil yang diperoleh untuk jangka pendek PDB mempengaruhi partisipasi pendidikan SMA; partisipasi pendidikan Perguruan Tinggi mempengaruhi PDB; partisipasi pendidikan SMA saling mempengaruhi dengan partisipasi pendidikan Perguruan Tinggi. Untuk jangka panjang diperoleh hasil APK PT dan APK SMA mempengaruhi PDB.
\end{abstract}

Kata kunci: Vector Error Correction Model, Pendidikan, PDB

\begin{abstract}
Educations are believed to be one of the elements that fosters a country's economy. In Indonesia, the student's participation is increase for the middle and high levels from 1994 - 2017 and at the same time there is also high economic growth. This study will look for an education participation relationship between basic level, secondary level, high level and Gross Domestic Product (GDP). The data in this study are secondary data on student participation and GDP in Indonesia taken from the Central Bureau of Statistics. The method to finding short-term relationships is the Granger Causality test and long-term relationships are Vector Error Correction Model (VECM) method. For stasioner test it is used Augment Dickey Fuller (ADF) method. The ADF test shows that the Gross Enrollment Rate (GER) variable of Elementery School and GER variabel of Junior High Scholl are stationary at the Level stage, so that the two variables are omitted from the initial model. The results for the short term are GDP affects to GER of Senior High Scholl, GER of University affects to GDP, GER of Senior High Schools affects to GER of University. For the long term GER of University and GER of Senior High Scholl affects to GDP.
\end{abstract}

Keyword: Vector Error Correction Model, Education, GDP 


\section{PENDAHULUAN}

Pendidikan menjadi kunci dalam menentukan keberhasilan sebuah negara, tetapi pengalokasian anggaran pendidikan sangat berbeda antara negara satu dengan lainnya. World Economic Forum (WEF) merilis laporan tahunan "The Organization for Economic Cooperation and Development" (OECD) tahun 2018 terkait bidang pendidikan dari 36 negara anggotanya. Salah satu tolak ukur dalam penilaian tersebut adalah sampai berapa banyak uang yang dihabiskan untuk pendidikan oleh masing-masing negara ini. Pada 2015 total pengeluaran rata-rata untuk pendidikan di negara-negara OECD adalah 11\%. Angka terendah adalah Yunani dengan total belanja sektor pendidikan sebanyak $6 \%$ dan hanya lima negara yang menghabiskan lebih dari 15\% untuk pendidikan, yaitu: Brasil, Chili, Meksiko, dan Selandia Baru. Chili menempati posisi ke-3 dengan belanja pendidikan sebanyak $16 \%$; Selandia Baru berada di peringkat ke-2 dengan total anggaran pendidikan sebesar 19\%; Kosta Rika menempati total anggaran belanja tertinggi dengan angka lebih dari 30\%; Inggris menduduki posisi ke-13; Amerika Serikat di posisi ke-17 dan Belanda di peringkat ke-20. Negara Finlandia menempati posisi ke-22 dengan anggaran pendidikan di bawah $15 \%$ dari total belanja negara (Harususilo, 2018).

Pada tahun 2019 Pemerintah Indonesia mengalokasikan anggaran sampai 20\% dari Anggaran Pendapatan dan Belanja Negara untuk sektor pendidikan dan anggaran tersebut meningkat secara tajam semenjak tahun 2015. Anggaran tersebut digunakan untuk Program Pendidikan Pintar, Bantuan Operasional Sekolah (BOS), Pembangunan/ Rehab sekolah dan Beasiswa Bidik Misi dengan struktur anggaran seperti pada gambar 1 (Kemenkeu, 2019).

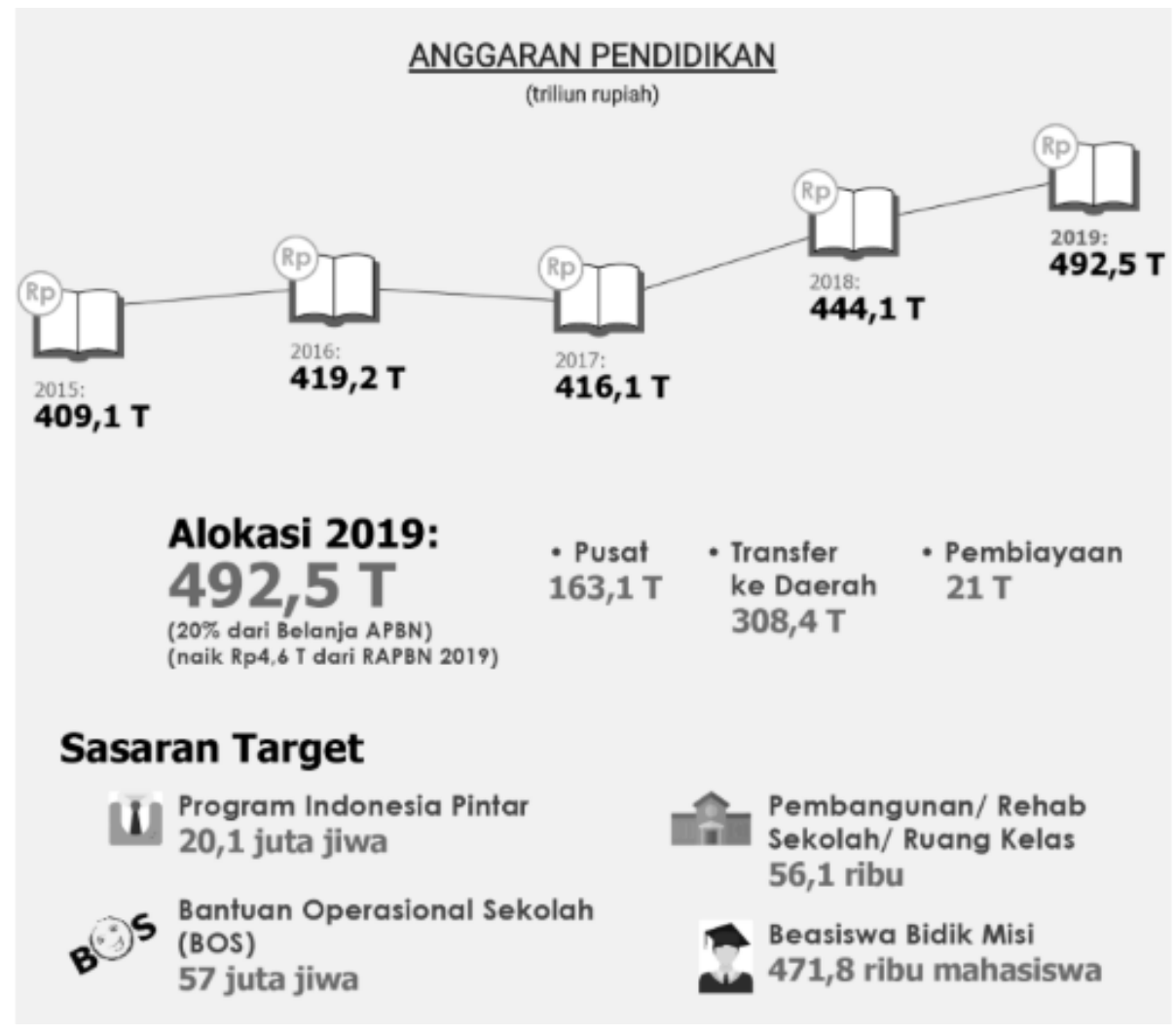

Gambar 1. Profil \& Alokasi Anggaran Pendidikan 
Dari gambar 1 terlihat bahwa secara nominal anggaran pendidikan sempat turun dari tahun 2016 ke 2017, tetapi kembali naik cukup besar semenjak 2018 sampai 2019. Berdasarkan data dari Kemendikbud tahun 2018 jumlah siswa tingkat dasar dan menengah kurang lebih 42,3 juta jiwa dan jumlah mahasiswa kurang lebih 7,5 juta jiwa, sehingga kurang lebih partisipasi siswa dan mahasiswa ada pendidikan di Indonesia sekitar 49,8 juta jiwa (Kemendikbud, 2019; Nursalikah, 2018). Sektor pendidikan di Indonesia telah mengalami kemajuan yang signifikan dan salah satu indikatornya adalah sebanyak $72,3 \%$ anak usia dini di Indonesia telah mengikuti proses pendidikan seperti yang disampaikan Menteri Pendidikan dan Kebudayaan (Mendikbud) Muhadjir Effendy dalam Sidang Umum United Nations Educational, Scientific, and Cultural Organization (UNESCO) Ke-39 di Paris, Prancis (Zubaidan, 2017).

Dari data Badan Pusat Statistik (BPS) Angka Partisipasi Kasar (APK) bahwa pendidikan di Indonesia khusus untuk tingkat Menengah dan Tinggi menunjukkan tren meningkat (gambar 2) dan hal ini seiring dengan terus meningkatnya anggaran pendidikan dari tahun ke tahun (BPS, 2019).

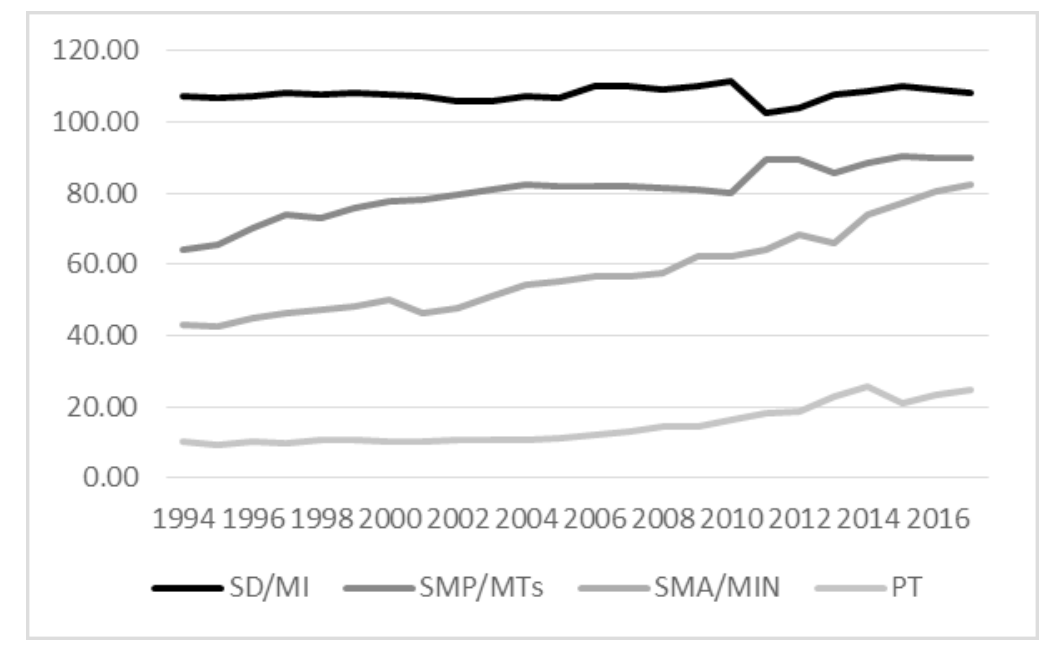

Gambar 2. Angka Partisipasi Kasar Peserta Didik Tahun 1994 - 2017

Disisi yang lain terdapat kenaikan pada gambar 3 (World Bank Group, 2019). Produk Nasional Bruto (PDB) seperti terlihat

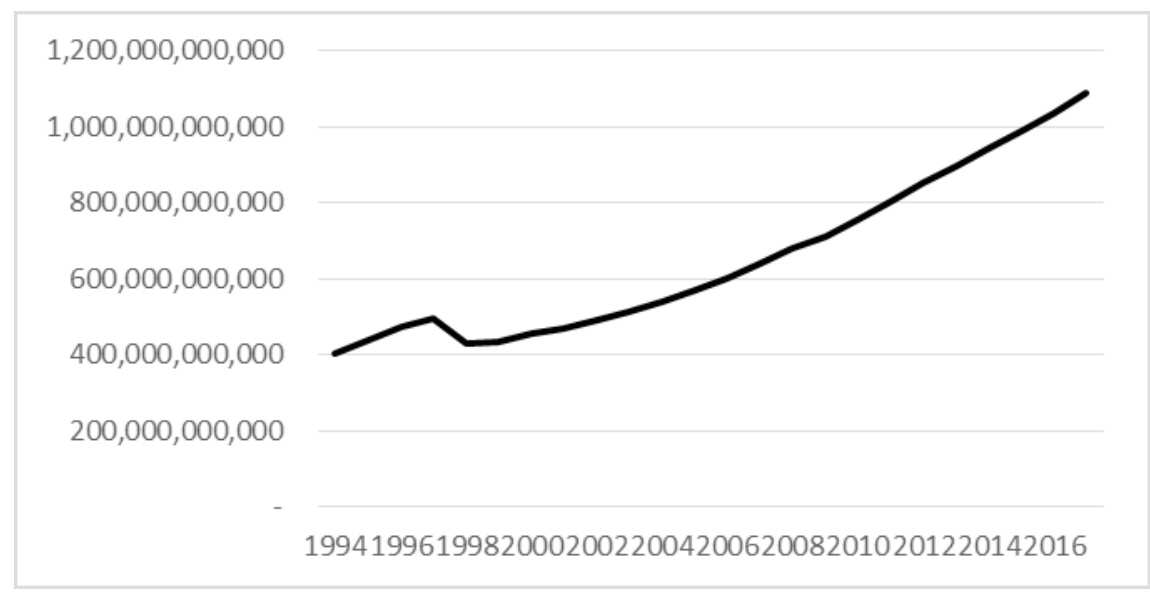

Gambar 3. Produk Domestik Bruto Konstan Indonesia 1994 - 2017 
Dari uraian diatas menimbulkan pertanyaan apakah terdapat hubungan antara kenaikan tingkat partisipasi pendidikan dengan kenaikan Produk Domestik Bruto (PDB) di Indonesia. Apabila terdapat hubungan maka program pastisipasi pendidikan menjadi hal yang sangat penting untuk menumbuhkan perekonomian Indonesia. Oleh karena itu pada penelitian ini bertujuan untuk melihat hubungan antara partisipasi pendidikan dengan pertumbuhan PDB di Indonesia.

Teori pertumbuhan modern telah melihat dari berbagai perspektif tentang apa yang secara fundamental menentukan pertumbuhanekonomi.Dalamanalisisempiris telah banyak upaya untuk melihat berbagai faktor mulai dari politik hingga geografi serta perbedaan pertumbuhan ekonomi di berbagai negara. Tunde \& Abimbola (2017) melakukan penelitian tentang hubungannya dengan pertumbuhan ekonomi di Nigeria dan diperoleh hasil bahwa Gross Domestic Product (GDP) dipengaruhi oleh total expenditure on education, gross fixed capital formation, total labor force, total recurrent expenditure, tetapi hubungan itu tidak timbal balik. Penelitan serupa juga dilakukan di Nepal dan diperoleh hasil bahwa partisipasi pendidikan di primary level, secondary level dan tersiery level mempengaruhi GDP (Nowak \& Dahal, 2016).

Mallick, dkk (2016) melakukan penelitian pada 14 negara di Asia tentang hubungan pendidikan dan pertumbuhan ekonomidandiperolehhasilbahwapendidikan di 14 negara tersebut mempengaruhi pertumbuhan ekonomi. Keempat belas negara tersebut adalah Bangladesh, China, Hong Kong, India, Japan, Malaysia, Nepal, Pakistan, The Philippines, Saudi Arabia, Singapore, Sri Lanka, Thailand dan Turkey. Variabel yang digunakan dalam penelitian ini adalah biaya pengeluaran pendidikan.
Penelitian yang sama dengan obyek di India dimana diperoleh hasil bahwa partisipasi siswa perempuan di primary level, secondary level dan tersiery level mempengaruhi GDP, sedang siswa laki-laki di tingkat tersiery level yang mempengaruhi GDP (Kotásková, dkk., 2018).

Pada penelitian lain yang dilakukan oleh Hanushek (2016) dengan obyek 32 negara maju dan diperoleh hasil bahwa pendidikan pada higher level mempengaruhi pertumbuhan ekonomi negara yang diteliti. Penelitian ini dikaitkan dengan besarnya investasi yang dikeluarkan dalam pendidikan suatu negara untuk memperoleh dampak pertumbuhan ekonomi. Hanif \& Arshed (2016) melakukan penelitian di negaranegara SAAR dan ditemukan hasil yang sama bahwa pendidikan itu mempengaruhi pertumbuhan ekonomi dengan variabel yang digunakan adalah pendidikan, inflation rate, physical capital dan GDP.

Dari beberapa penelitian empiris yang dilakukan pada dekade 5 tahun di atas terlihat bahwa penelitian dilakukan untuk mencari hubungan pertumbuhan ekonomi dan pertumbuhan tingkat partisipasi pendidikan. Pada penelitian yang disebutkan diatas sebagian besar metode dalam mencari hubungan antara partisipasi pendidikan dan ekonomi menggunakan granger causality dan VECM. Metode ini banyak digunakan di dalam mencari hubungan antar variabel macroeconomic baik itu hubungan jangka pendek maupun hubungan jangka panjang. Pendidikan dalam kontek ini merupakan salah satu bagian atau variabel dari macroeconomic. Dalam penelitian ini PDB digunakan sebagai variabel terikat dan variabel bebasnya berupa tingkat partisipasi pendidikan mulai dari tingkat dasar, menengah dan tinggi. Berdasarkan peneltian terdahulu dapat dibuat hipotesa bahwa partisipasi pendidikan untuk tingkat dasar, menengah dan tinggi di 
Indonesia dapat mempengaruhi pertumbuhan PDB dan model dari hubungan antar variabel bebas dan terikatnya dapat digambarkan sebagai berikut,

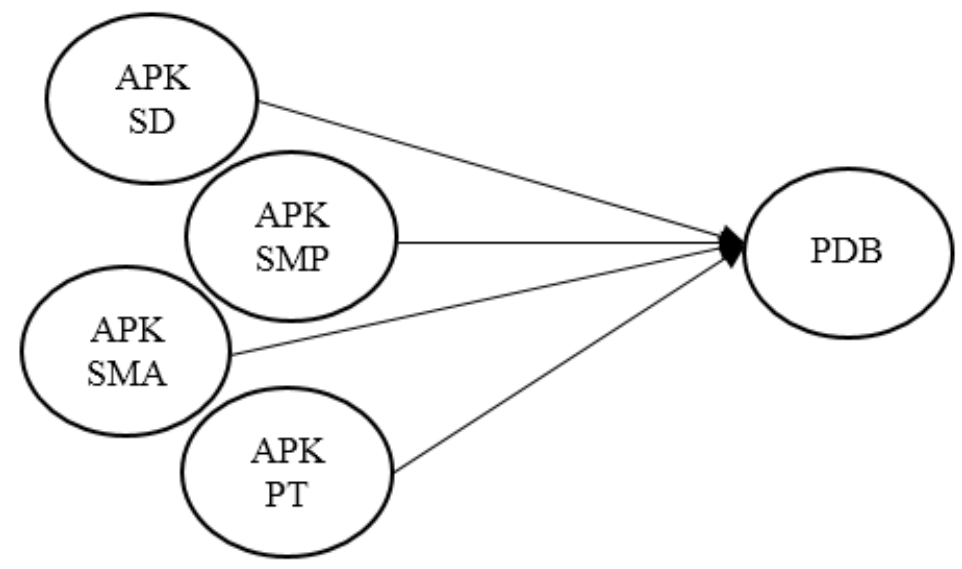

Gambar 4. Model Hubungan APK dan PDB

Keterangan pada gambar 4. APK adalah Angka Partisipasi Kasar; SD adalah Sekolah Dasar; SMP adalah Sekolah Menengah Pertama; SMA adalah Sekolah Menengah Atas dan PT adalah Perguruan Tinggi.

\section{METODE PENELITIAN}

Penelitian ini merupakan penelitian kuantitatif dan sesuai definisinya bahwa "Penelitian kuantitatif adalah suatu pendekatan penelitian yang bersifat obyektif, mencakup pengumpulan dan analisa data kuantitatif dan menggunakan metoda statistik" (Hermawan, 2009). Obyektif dalam hal ini karena data yang diambil merupakan data makro ekonomi di Indonesia yang terus bergerak sesuai dengan kondisi perekonomian, sehingga analisanyapun bersifat kuantitatif merujuk kepada angkaangka makro ekonomi tersebut.

Berdasarkan klasifikasi desainnya maka masuk padaklasifikasiperiodareferensi, karena variabel data yang dijadikan obyek penelitian adalah data time series berupa data histori partisipasi pendidikan dan PDB dari 24 tahun yang lalu. Sedang berdasarkan pengelompokannya penelitian ini merupakan penelitian korelational. Menurut Frankel, dkk., (2009) "Penelitian korelasional adalah penelitian yang digunakan untuk mempelajari hubungan dan tingkat hubungan antara dua variabel atau lebih" dan pada penelitian ini dicari hubungan antara variabel partisipasi pendidikan dan PDB di Indonesia.

\subsection{Data Penelitian}

Pada penelitian ini diambil data APK siswa SD, SMP dan SMA serta mahasiswa dari tahun 1994 - 2017 yang diambil dari situs resmi BPS. Untuk data PDB diambil data dari situs resmi World Bank dari tahun 1994 - 2017 dan untuk data PDB ini diambil data PDB konstan.

\subsection{Analisa Penelitian}

Untuk mencari hubungan antara variabel digunakan metode VECM dimana dilakukan tahapan sebagai berikut:

1. Membuat inisialisasi model dengan pendekatan Ordinary Least Square (OLS).

2. Pengujian kestasioneran data menggunakan metode Augment Dickey Fuller (ADF).

3. Pengujian kestasioneran residu persamaan OLS dengan menggunakan metode Augment Dickey Fuller (ADF).

4. Pengujian Kointegrasi dengan metode Johansen. 
5. Analisa hubungan jangka dengan Granger Causality Test.

6. Analisa hubungan jangka panjang dengan metode Vector Error Corection Model (VECM).

\section{HASIL DAN PEMBAHASAN}

\subsection{Hasil}

\subsubsection{Inisialisasi Persamaan}

Pada penelitian ini digunakan 4 variabel bebas dan satu variabel tidak bebas dimana PDB variabel tidak bebasnya. Sedangkan 4 variabel bebas tersebut adalah : 1. Angka Partisipasi Kasar (APK) Sekolah

\section{Dasar (SD)}

2. Angka Partisipasi Kasar (APK) Sekolah Menengah Pertama (SMP)

3. Angka Partisipasi Kasar (APK) Sekolah Menengah Atas (SMA)

4. Angka Partisipasi Kasar(APK) Perguruan Tinggi (PT)

Variabel APK SD dalam persamaan ini akan disimbolkan ASD; variabel APK SMP akan disimbolkan ASMP; variabel APK SMA akan disimbolkan ASMA; variabel APK PT akan disimbolkan APT dan variabel PDB akan disimbolkan PDB, sehingga persamaan akan menjadi:

$$
P D B=\beta_{0}+\beta_{1} A S D+\beta_{2} A S M P+\beta_{3} A S M A+\beta_{4} A P T
$$

Model ini tidak bisa langsung digunakan karena perbedaan data yang cuku besar antara PDB dan APK, sehingga menurut Tukey (1977) data tersebut harus dilakukan exploratory atau dipecahkan sehingga mempunyai nilai yang berdekatan dengan dan dalam penelitian ini ditransformasikan ke bentuk $\ln$. Oleh karena itu untuk mengolah data variabel, maka semua variabel ditranformasikan ke bentuk $L n$, sehingga persamaannya akan menjadi,

$$
L P D B=\beta_{0}+\beta_{1} L A S D+\beta_{2} L A S M P+\beta_{3} L A S M A+\beta_{4} L A P T
$$

\subsubsection{Uji Stasioner}

Data time series terbagi menjadi dua berdasarkan sifatnya yaitu data stasioner dan data non stasioner. Mengetahui sifat data sangat penting karena akan menentukan metode apa yang akan digunakan dalam menyelesaikan suatu model. Menurut Soejoeti (1987) suatu deret data dikatakan stasioner bila nilai tengah (mean), varian dan kovarian dari deret tersebut tidak dipengaruhi oleh perubah pada waktu pengamatan, sehingga proses berada pada kesetimbangan statistik. Pada penelitian ini uji stationer yang digunakan adalah metoda Augmened Dickey Fuller (ADF). Uji stationer dengan menggunakan metoda ADF merupakan pengujian stationer dengan mencari apakah mengandung akar unit (unit root) pada data urutan data tersebut.

Data dikatakan stasioner bila probabilitasnya kurang dari $0,05 \quad(<$ $0,05)$ atau nilai t-statistik lebih kecil dari pada nilai critical value. Pengujian dengan ADF ini untuk tahap pertama menggunakan tingkat level, bila pada tingkat ini data tidak stasioner maka dilanjutkan ke tingkat first difference. Apabila pada tingkat first difference juga tidak stasioner maka dilajutkan ke tingkat second difference dan demikian seterusnya. Uji stationer dengan ADF ini menggunakan software eviews. Dari data variabel yang digambarkan pada grafik diatas diasumsikan oleh penulis bahwa data tidak menunjukkan tren yang tetap sehingga setting parameter persamaan di ADF digunakan intercept. 
Tabel 1. Hasil Uji Stationer dengan ADF

\begin{tabular}{clrr}
\hline Variabel & Tingkatan & \multicolumn{1}{c}{ t Statistik } & Prob \\
\hline \multirow{3}{*}{ LPDB } & Level & 1.720 .459 & 0.9992 \\
\cline { 2 - 4 } & 1 st Diff & -3.337 .898 & 0.0259 \\
\cline { 2 - 4 } & 2 st Diff & $-5.822 . .867$ & 0.0001 \\
\hline \multirow{3}{*}{ LASD } & Level & $-3.180 . .069$ & 0.0345 \\
\cline { 2 - 4 } & 1 st Diff & -5.190 .674 & 0.0004 \\
\cline { 2 - 4 } & 2 st Diff & -5.995 .516 & 0.0001 \\
\hline \multirow{3}{*}{ LASMP } & Level & -2.370 .963 & 0.1603 \\
\cline { 2 - 4 } & 1 st Diff & -4.904 .653 & 0.0009 \\
\cline { 2 - 4 } & 2 st Diff & -7.551 .618 & 0.0000 \\
\hline \multirow{3}{*}{ LASMA } & Level & 0.473056 & 0.9817 \\
\cline { 2 - 4 } & 1 st Diff & -6.105 .771 & 0.0001 \\
\cline { 2 - 4 } & 2 st Diff & -4.209 .435 & 0.0057 \\
\hline \multirow{3}{*}{ LAPT } & Level & 0.454148 & 0.9809 \\
\cline { 2 - 4 } & 1 st Diff & -5.486 .687 & 0.0002 \\
\cline { 2 - 4 } & 2 st Diff & -6.996 .919 & 0.0000 \\
\hline
\end{tabular}

Variabel stasioner pada prob $t$ statistic $<0,1$ atau 0,05 atau 0,01 , dan hasil pengujian dari tabel 1 terlihat bahwa bila prob $t$ statistic $<$ 0,1 maka LASD \& LASMP stasioner pada tingkat Level; bila prob $t$ statistic $<0,05$ maka LASD stasioner pada tingkat Level; bila $t$ statistic $<0,01$ maka semua variabel tidak stasioner pada tingkat Level. Sedangkan semua variabel stasioner pada $t$ statistic $<0,1$ atau 0,05 atau 0,01 pada tingkat $1{ }^{\text {st }}$ different. Dengan melihat kondisi diatas maka LASD dan LASMP dihilangkan dari variabel karena prob $t$ statistic $<0,1$ sehingga persamaan menjadi,

$$
L P D B=\beta_{0}+\beta_{3} L A S M A+\beta_{4} L A P T .
$$

\subsubsection{Uji Residual}

Uji residual ini dilakukan untuk melihat apakah persamaan (3) bukan persamaan regresi palsu.

Tabel 2. Hasil Uji Residual dengan ADF

\begin{tabular}{cllc}
\hline Variabel & Tingkatan & t Statistik & Prob \\
\hline \multirow{2}{*}{ RESIDUAL } & Level & -3.301 .697 & 0.0267 \\
\cline { 2 - 4 } & 1 st Diff & -5.344 .317 & 0.0004 \\
\cline { 2 - 4 } & 2 st Diff & -5.732 .590 & 0.0002 \\
\hline
\end{tabular}

Pada tabel 2 terlihat bahwa residual prob $t$ statistic $<0,1$ atau 0,05 atau 0,01, sehingga stasioner pada tingkat level dan persamaan (2) tidak palsu dan proses dilanjutkan ke tahap berikutnya.

\subsubsection{Pengujian Kointegrasi}

Pengujian kointegrasi digunakan untuk melihat terjadinya hubungan jangka panjang antar variabel. Dalam kondisi ini gabungan antar 2 variabel atau lebih dalam jangka panjang akan menjadi stasioner. Dalam melakukan uji kointegrasi perlu dicari dulu lag length criteria atau lag optimal dari persaman. Untuk mencari lag length criteria terlebih dahulu dicari laglength yang maksimal dengan cara mengenerate parameter dari persamaan sampai diperoleh angka lag maksimal. 
Dari simulasi diperoleh angka lag maksimal $=4$. Nilai Lag maksimal ini digunakan untuk mencari paramater lag to include pada saat menghitung lag length criteria atau log optimal. Metode yang digunakan untuk mencari lag optimal adalah metoda Likelihood Rasio (LR), Final Prediction Error (FPE), Akaike Information Criterion (AIC), Schwatcz Criterion (SC) dan Hannan-Quinn Criterion (HC) dimana diperoleh hasil seperti pada tabel 3.

Tabel 3. Lag Optimal

\begin{tabular}{ccccccc}
\hline Lag & LogL & LR & FPE & AIC & SC & HQ \\
\hline 0 & 5.687 .576 & NA & $1.19 \mathrm{e}-06$ & -5.131 .025 & -4.981 .808 & -5.098 .641 \\
\hline 1 & 1.118 .448 & $88.99754^{*}$ & $1.51 \mathrm{e}-08$ & -9.509 .032 & $-8.912162^{*}$ & -9.379 .495 \\
\hline 2 & 1.219 .551 & 1.348 .033 & $1.45 \mathrm{e}-08^{*}$ & $-9.614796^{*}$ & -8.570 .247 & $-9.388081^{*}$ \\
\hline 3 & 1.292 .676 & 7.660 .692 & $2.02 \mathrm{e}-08$ & -9.454 .053 & -7.961 .878 & -9.130 .213 \\
\hline
\end{tabular}

Dengan metode LR, SC diperoleh lag optimal $=1$ dan FPE, AIC \& HQ diperoleh lag optimal $=2$ dan nilai lag yang bisa diambil 2 (diambil Lag dengan metoda terbanyak).
Dengan memasukkan lag optimal $=1$ pada metode Johansen diperoleh hasil pada tabel 4 dan tabel 5,

Tabel 4. Hasil Uji Johansen Metoda Trace

\begin{tabular}{ccccc}
\hline $\begin{array}{c}\text { Hypothesized } \\
\text { No. of CE(s) }\end{array}$ & Eigenvalue & $\begin{array}{c}\text { Trace } \\
\text { Statistic }\end{array}$ & $\begin{array}{c}\text { 0.05 Critical } \\
\text { Value }\end{array}$ & Prob.** \\
\hline None $^{*}$ & 0.727346 & 4.158 .261 & 2.979 .707 & 0.0014 \\
\hline Atmost 1 & 0.430313 & 1.429 .203 & 1.549 .471 & 0.0753 \\
\hline Atmost 2 & 0.111219 & 2.476 .000 & 3.841 .466 & 0.1156 \\
\hline
\end{tabular}

Tabel 5. Hasil Uji Johansen Metoda Max Eigen

\begin{tabular}{ccccc}
\hline $\begin{array}{c}\text { Hypothesized } \\
\text { No. of CE(s) }\end{array}$ & Eigenvalue & $\begin{array}{c}\text { Max-Eigen } \\
\text { Statistic }\end{array}$ & $\begin{array}{c}\text { 0.05 Critical } \\
\text { Value }\end{array}$ & Prob.** \\
\hline None $*$ & 0.727346 & 2.729 .057 & 2.113 .162 & 0.0060 \\
\hline Atmost 1 & 0.430313 & 1.181 .603 & 1.426 .460 & 0.1177 \\
\hline Atmost 2 & 0.111219 & 2.476 .000 & 3.841 .466 & 0.1156 \\
\hline
\end{tabular}

Dari uji Johansen diperoleh bahwa baik dengan cara trace statistic maupun max eigen statistic terdapat 1 persamaan yang kointegrasi.

\subsubsection{Granger Causality Test}

Untuk melihat arah hubungan antar variabel setelah terbukti data stasioner bisa menggunakan granger causality test seperti pada table 6 .

Tabel 6. Hasil Granger Causality Test

\begin{tabular}{lccc}
\hline Null Hypothesis: & Obs & F-Statistic & Prob. \\
\hline LASMA does not Granger Cause LPDB & 22 & 1.26459 & 0.3076 \\
LPDB does not Granger Cause LASMA & & 4.05364 & 0.0364 \\
\hline LAPT does not Granger Cause LPDB & 22 & 0.62724 & 0.5460 \\
LPDB does not Granger Cause LAPT & & 5.22766 & 0.0170 \\
\hline LAPT does not Granger Cause LASMA & 22 & 3.03226 & 0.0748 \\
LASMA does not Granger Cause LAPT & & 4.47347 & 0.0275 \\
\hline
\end{tabular}


Dari uji ini dengan prob $<0,1$ diperoleh hasil,

1. LAPDB mempengaruhi LASMA.

2. LAPDB mempengaruhi LAPT.

3. LASMA mempengaruhi LAPT.

4. LAPT mempengaruhi LASMA.

\subsubsection{Uji VECM}

Hasil uji VECM dengan Eviews diperoleh hasil untuk persamaan jangka Panjang sebagai berikut:

$$
L P D B=22,3578+0,993497 L S M A+0,302203 L P T .
$$

Sedang untuk jangka pendek dapat dilihat pada pada tabel 7 .

Tabel 7. Hasil VECM Hubungan Jangka Pendek

\begin{tabular}{|c|c|c|c|}
\hline Error Correction: & D(LPDB) & D(LASMA) & D(LAPT) \\
\hline \multirow{3}{*}{ CointEq1 } & -0.414258 & 0.651907 & 1.096670 \\
\hline & $(0.38442)$ & $(0.31452)$ & $(0.64086)$ \\
\hline & {$[-1.07763]$} & [2.07268] & [1.71125] \\
\hline \multirow{3}{*}{$\mathrm{D}(\operatorname{LPDB}(-1))$} & 0.527227 & -0.411126 & -0.381039 \\
\hline & $(0.34543)$ & $(0.28263)$ & $(0.57586)$ \\
\hline & [1.52629] & {$[-1.45467]$} & {$[-0.66168]$} \\
\hline \multirow{3}{*}{$\mathrm{D}(\operatorname{LPDB}(-2))$} & 0.063563 & -0.438930 & -0.488528 \\
\hline & $(0.38587)$ & $(0.31571)$ & $(0.64328)$ \\
\hline & {$[0.16473]$} & [-1.39029] & {$[-075944]$} \\
\hline \multirow{3}{*}{ D(LASMA(-1)) } & -0.063074 & -0.058066 & -0.010126 \\
\hline & $(0.32251)$ & $(0.26388)$ & $(0.53766)$ \\
\hline & {$[-0.19557]$} & {$[-0.22005]$} & {$[-0.01883]$} \\
\hline \multirow{3}{*}{ D(LASMA(-2)) } & 0.041794 & -0.116021 & 0.773799 \\
\hline & $(0.28762)$ & $(0.23533)$ & $(0.47949)$ \\
\hline & {$[0.14531]$} & {$[-0.49302]$} & {$[1.61380]$} \\
\hline \multirow{3}{*}{ D(LAPT(-1)) } & 0.188467 & 0.122585 & -0.135476 \\
\hline & $(0.13779)$ & $(0.11274)$ & $(0.22971)$ \\
\hline & {$[1.36780]$} & {$[1.08736]$} & {$[-0.58978]$} \\
\hline \multirow{3}{*}{ D(LAPT(-2)) } & 0.006369 & 0.042433 & -0.144735 \\
\hline & $(0.13771)$ & $(0.11267)$ & $(0.22957)$ \\
\hline & {$[0.04625]$} & [0.37662] & {$[-0.63047]$} \\
\hline \multirow{3}{*}{$\mathrm{C}$} & 0.008001 & 0.062784 & 0.067859 \\
\hline & $(0.03056)$ & $(0.02501)$ & $(0.05095)$ \\
\hline & {$[0.26179]$} & {$[2.51079]$} & [1.33185] \\
\hline
\end{tabular}

Unuk menganalisa dibandingkan antara hasil $t$-test diatas dengan tabel distribusi $t$-test. Berdasarkan tabel dengan $n=24$ dan $\alpha=0,1 \quad \mathrm{t}=1,311784$. Hasil uji VECM diperoleh $(\alpha=0,1)$,

a. LPDB (-1) berpengaruh positif pada LPDB.

b. LAPT (-1) berpengaruh positif pada LPDB.

c. LASMA (-2) berpengaruh positif pada LAPT. d. LPDB (-1) berpengaruh negative pada LASMA.

e. LPDB (-2) berpengaruh negative pada LASMA.

\subsection{Pembahasan}

\subsubsection{Variabel Data}

Seperti disampaikan diatas bahwa variabel bebas yang digunakan pada penelitian ini adalah APK di Indonesia. APK adalah jumlah siswa pada tingkat level tertentu dibandingkan dengan jumlah anak- 
anak pada usia yang seharusnya berpartisipasi pada pendidikan level tersebut. Bila analisa pada gambar 2. terlihat bahwa untuk tingkat SD tingkat partisipasinya tumbuh dengan angka kecil sejak 1994 bahkan sempat terjadi penurunan di tahun 2011 dan kembali tumbuh pada tahun-tahun berikutnya. Pada tingkat SD ini terlihat bahwa angka partisipasinya lebih dari $100 \%$ dan menunjukkan bahwa siswa yang sekolah di SD usianya melebihi jumlah anak-anak dalam hal ini yang berusia 7 - 12 tahun. Dari gambaran APK pada tingkat SD maka partisipasi masyarakat untuk pendidikan dasar sangat tinggi atau dapat dikatakan bahwa hampir semua anak usia 7-12 tahun telah berpartisipasi pada pendidikan dasar. Pada tingkat SMP terjadi pertumbuhan sekitar 40\% untuk APK dari tahun 1994 - 2017, sedang untuk tingkat SMA terjadi pertumbuhan yang lebih besar sekitar 91\%. Bila dilihat APK untuk SMP pada tahun 2017 mencapai 90\% sedangkan SMA mencapai 82,25\%, sehingga ini menunjukkan bahwa tingkat partisipasi masyarakat terhadap pendidikan menengah semakin tinggi. Untuk APK pendidikan tinggi terjadi lonjakan pertumbuhan yang sangat tinggi dari tahun 1994 - 2017 yaitu kurang lebih 147\% meskipun secara nilai dari APK kurang lebih 25\% pada tahun 2017. Data PDB yang diambil untuk penelitian ini adalah PDB konstan, karena angka PDB konstan tidak terpengaruh terjadinya fluktuasi harga dan secara grafik dilihat pada gambar 3. Pertumbuhan PDB sejak tahun 1994 2017 mencapai kurang lebih 170\%. Dari data juga terlihat sempat terjadi penurunan di tahun 1997-1998 dimana Indonesia pada saat itu terkena krisis ekonomi yang membuat kinerja perekonomian Indonesia turun.

\subsubsection{Uji Stasioner}

Persyaratan mutlak yang harus dipenuhi untuk mencari hubungan antar variabel dengan metode VECM adalah semua variabel harus stasioner pada tingkat 1 st different atau 2 st different atau lebih. Berdasarkan uji stasioner dengan metode ADF diperoleh hasil bahwa variabel LASD dan LASMP stasioner pada tingkat Level, sehingga LSD dan LSMP dikeluarkan dari model. Untuk LASMA, LPT dan LPDB pada tingkat $1^{\text {st }}$ different mempunyai sifat stasioner, sehingga variabel tersebut bisa lanjut untuk pengujian kointegrasi.

\subsubsection{Uji Residual}

Persamaan pada penelitian ini menggunakan pendekatan OLS yang merupakan persamaan regresi, oleh karena itu perlu dilakukan uji persamaan apakah persamaan tersebut benar merupakan persamaan regresi atau bukan. Dari hasil residual dengan pengujian menggunakan ADF diperoleh bahwa persamaan tersebut stasioner pada tingkat level, maka hasil ini menunjukkan bahwa persamaan tersebut merupakan regresi yang tidak sporious.

\subsubsection{Pengujian Kointegrasi}

Lag length criteria/ lag optimal yang dicari dengan metode lag stucture diperoleh Lag $=2$, sehingga uji kointegrasi bisa dilakukan dengan lag tersebut. Lag optimal yang sudah diperoleh dapat digunakan untuk mencari hubungan kausalitas dengan Granger Causaliy, sedang untuk hubungan jangka panjang dan pendek yang menggunakan metode VECM harus memenuhi persyaratan adanya kointegrasi. Dengan metode Johansen diperoleh hasil bahwa terdapat 1 persamaan yang terkointegrasi baik itu dengan cara trace maupun Max Eigen. Sifat adanya kointegrasi atau tidak menentukan apakah pencarian hubungan menggunakan Variabel Autoregresive (VAR) atau VECM, bila ada sifat kointegrasi maka pnyelesain menggunakan metode VECM. Hasil uji Johansen menunjukkan bahwa satu persamaan mempunyai sifat kointegrasi, sehingga persamaan ini bisa diselesaikan 
dengan metode VECM untuk mencari hubungan jangka panjangnya.

\subsubsection{Granger Causality Test}

Untuk Granger Causality Test tidak diperlukan uji kointegrasi, sehingga hanya dengan syarat data stasioner maka metode ini bias digunakan. Uji ini menggunakan $\alpha=$ 0,1 dengan $L a g=2$ dan dari uji ini diperoleh hasil bahwa dalam jangka pendek terdapat hubungan sebagai berikut,

a. PDB mempengaruhi APK SMA.

b. PDB mempengaruhi APK PT.

c. APK SMA mempengaruhi APK PT.

d. APK PT mempengaruhi APK SMA.

Dari hubungan diatas terlihat juga bahwa terjadi hubungan dua arah antara APK SMA dengan APK PT, sedang PDB dengan APK SMA dan PDB dengan APK PT hanya mempunyai hubungan satu arah. Pada pengujian ini tidak diketahui hubungan tersebut positif atau negatif serta variabel pada posisi apa yang mempengaruhi variabel lainnya. Sebagai contoh salah satu hasil diatas yaitu, PDB mempengaruhi APK SMA; pada pernyataan ini tidak dijelaskan PDB periode kapan yang mempengaruhi APK SMA dan apakah PDB mempengaruhi positif atau negatif pada APK SMA.

\subsubsection{Uji VECM}

Pada hubungan jangka panjang dengan $l a g=2, \quad \alpha=0,1$ menghasilkan persamaan (4) dan dari persamaan tersebut terlihat bahwa tingkat partisipasi pendidikan SMA mempunyai pengaruh yang lebih besar dibandingkan partisipasi pendidikan PT dalam mendapatkan angka PDB. Angka partisipasi pendidikan untuk SMA dan PT mempunyai dampak positif terhadap PDB, oleh karena itu peningkatan partisipasi SMA dan PT akan meningkatkan PDB Indonesia. Untuk hubungan jangka pendek dengan metode VECM dan dengan lag $=2, \alpha=0,1$ diperoleh hasil sebagai berikut ini:

a. PDB pada satu tahun sebelumnya berpengaruh positif terhadap PDB saat ini, sehingga secara jangka panjang angka PDB saat ini mempunyai peluang lebih besar dari PDB satu tahun sebelumnya.

b. Partisipasi Perguruan Tinggi pada satu tahun sebelumnya berpengaruh positif terhadap PDB, sehingga secara jangka Panjang semakin tinggi partisipasi Perguruan Tinggi akan mempengaruhi PDB.

c. Partisipasi SMA pada dua tahun sebelumnya akan mempengaruhi secara positif partisipasi Perguruan Tinggi.

d. PDB pada satu tahun sebelumnya berpengaruh negatif pada tingkat partisipasi SMA. Hal ini mengakibatkan apabila PDB turun maka APK SMA naik demikian pula sebalikanya.

e. PDB pada dua tahun sebelumnya berpengaruh negatif pada tingkat partisipasi SMA.

Hasil Analisa hubungan jangka pendek dengan VECM mempunyai hasil yang sama dengan uji Granger Causality, tetapi terdapat perbedaan arah hubungan pada partisipasi Pendidikan PT terhadap PDB. Menurut uji Granger Causality PDB mempengaruhi partisipasi pendidikan PT, tetapi menurut analisa VECM pastisipasi pendidikan PT mempengaruhi PDB. Dalam kasus ini hasil dipilih yang menggunakan analisa VECM dengan pertimbangan VECM merupakan pengembangan dari Granger Causality dan banyak peneliti mereferensikan hal tersebut.

Dalam jangka pendek terdapat 3 variabel yang mempengaruhi variabel lainnya secara positif, yaitu, PDB, APK PT dan APK SMA sehingga naik atau turunnya variabel tersebut akan berdampak naik atau turunnya PDB dan APK PT. Ketiga variabel tersebut mempengaruhi secara positif dengan periode yang berbeda, PDB satu tahun sebelumnya berpengaruh pada PDB; APK PT satu tahun sebelumnya berpengaruh pada PDB; APK 
SMA dua tahun sebelumnya berpengaruh kepada APK PT. Selain itu terdapat 1 variabel yang mempengaruhi secara negative pada 1 variabel lainnya tetapi dengan 2 periode yang berbeda yaitu, PDB satu tahun dan dua tahun sebelumnya akan berpengaruh secara terbalik pada APK SMA, sehingga bila PDB naik maka APK SMA akan turun.

Dari hasil diatas ada beberapa hal yang perlu diperhatikan dan ditindaklanjuti terkait dengan kenaikan PDB dalam jangka pendek yang akan menurunkan angka partisipasi pendidikan SMA meskipun secara jangka panjang angka partisipasi SMA mempengaruhi secara positif PDB. Perlu dilakukan pendalaman mengapa hasil ini bisa terjadi. Dengan melihat hasil diatas maka untuk kondisi di Indonesia model hubungan partisipasi pendidikan dengan pertumbuhan ekonomi strukturnya sebagai berikut: variabel bebasnya adalah APK Perguruan Tinggi dan APK SMA; variabel terikatnya adalah PDB.

\section{KESIMPULAN}

Hipotesa pada penelitian ini adalah Angka Partisipasi Kasar pendidikan tingkat SD, SMP, SMA dan PT mempengaruhi PDB, tetapi dalam proses pengujian stasioner APK SD dan SMP tidak memenuhi persyaratan untuk metoda VECM maka variabel APK SD dan SMP dihilangkan. Oleh karena itu model hanya melibatkan APK SMA, PT dan PDB dimana variabel bebasnya adalah APK SMA dan APK PT, sedang variabel terikatnya PDB. Kesimpulan yang diperoleh dari penelitian ini adalah untuk jangka pendek: PDB mempengaruhi partisipasi pendidikan SMA; partisipasi pendidikan Perguruan Tinggi mempengaruhi PDB; partisipasi pendidikan SMA saling mempengaruhi dengan partisipasi pendidikan Perguruan Tinggi. Sedangkan untuk jangka panjang : partisipasi pendidikan Perguruan Tinggi dan partisipasi pedidikan SMA mempengaruhi PDB.

\section{DAFTAR RUJUKAN}

Badan Pusat Statistik - BPS. (2019). Indikator Pendidikan 1994-2017. [Online] Diakses dari https://pendidikan. bps.go.id/statictable/2010/03/19/1525/indikator-pendidikan-1994-2017.html.

Frankel, J. R., Wallen, N., \& Hyun, H. (2009). How to Design and Evaluate Research in Education. New York, McGraw-Hill Companies.

Hanif, N. \& Arshed, N. (2016). Relationship between School Education and Economic Growth: SAARC Countries. International Journal of Economics and Financial.

Hanushek, E. A. (2016). Will more higher education improve economic growth?. Oxford Review of Economic Policy, Volume 32, Number 4, 2016, pp. 538-552.

Harususilo, Y. E. (2018). 5 Negara dengan Alokasi Anggaran Pendidikan Terbesar. [Online] Diakses dari https:// edukasi.kompas.com/read/2018/10/30/08000011/5-negara-dengan-alokasi-anggaran-pendidikanterbesar.

Hermawan, A. (2009). Penelitian Bisnis, Grasindo.

Kemendikbud (2019). Statistik Pendidikan. [Online] Diakses dari http://statistik.data.kemdikbud.go.id/index.php/ page (di akses 23 Maret 2019).

Kemenkeu. (2019). Anggaran 2019. [Online] Diakses dari di https://pendidikan.kemenkeu.go.id/apbn2019.

Kotásková, S. K., Procházka, P., Smutka, L., Maitah, M., Kuzmenko, E., Kopecká, M., Hönig, V. (2018). The Impact of Education on Economic Growth: The Case of India. ACTA UNIVERSITATIS AGRICULTURAE ET SILVICULTURAE MENDELIANAE BRUNENSIS, Volume 66.

Mallick, L., Das, P.K., \& Pradhan, K. C. (2016). Impact of educational expenditure on economic growth in major Asian countries: Evidence from econometric analysis. Theoritical and Applied Economics Volume XXIII, No. 2(607), Summer pp. 173-186. 
Nowak, A. Z. \& Dahal, G. (2016). The contribution of education to economic growth: Evidence from Nepal. International Journal of Economic Sciences, 2016, vol. 5, issue 2, 22-41

Nursalikah, A. (2018). Jumlah Mahasiswa Indonesia Masih Sedikit. [Online] Diakses dari https://pendidikan. republika.co.id/berita/pendidikan/dunia-kampus/18/11/12/pi2o7r366-jumlah-mahasiswa-indonesiamasih-sedikit.

Soejoeti, Z. (1987). Analisis Runtun Waktu. Karunika Jakarta.

Tukey, J. W. (1977).Exploratory Data Analisys. Addison-Welley Publishing Company.

Tunde, O. S. \& Abimbola, A. B. (2017). Granger Causality Relationship Between Education and Economic Growth in Nigeria. International Journal of Recent Research in Commerce Economics and Management (IJRRCEM).

World Bank Group. (2019). GDP (current US\$). [Online] Diakses dari https://data.worldbank.org/country/ indonesia.

Zubaidan, N. (2017). Mendikbud: Pendidikan Indonesia Alami Kemajuan Signifikan. [Online] Diakses dari https://nasional.sindonews.com/read/1254817/144/mendikbud-pendidikan-indonesia-alami-kemajuansignifikan-1509938303. 